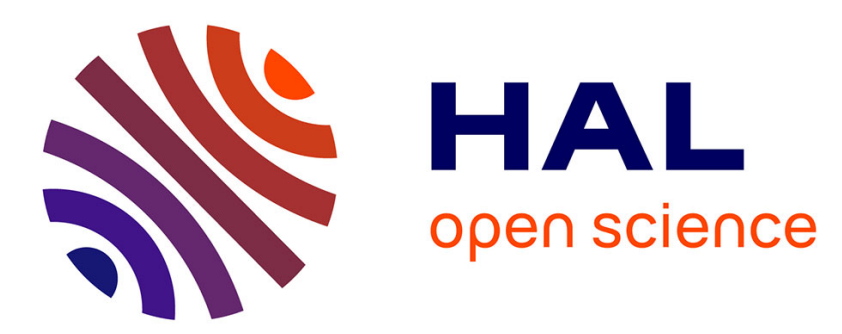

\title{
Retail decentralization and land use regulation policies in suburban and rural communities: The case of the Île-de-France region
}

\author{
André Torre, Océane Peiffer Smadja
}

\section{- To cite this version:}

André Torre, Océane Peiffer Smadja. Retail decentralization and land use regulation policies in suburban and rural communities: The case of the Île-de-France region. 54. Colloque de l'ASRDLF / 15. Colloque ERSA, Association de Science Régionale de Langue Française (ASRDLF). FRA., Jul 2017, Athenes, Greece. 2 p. hal-02791260

\section{HAL Id: hal-02791260 \\ https://hal.inrae.fr/hal-02791260}

Submitted on 5 Jun 2020

HAL is a multi-disciplinary open access archive for the deposit and dissemination of scientific research documents, whether they are published or not. The documents may come from teaching and research institutions in France or abroad, or from public or private research centers.
L'archive ouverte pluridisciplinaire HAL, est destinée au dépôt et à la diffusion de documents scientifiques de niveau recherche, publiés ou non, émanant des établissements d'enseignement et de recherche français ou étrangers, des laboratoires publics ou privés. 


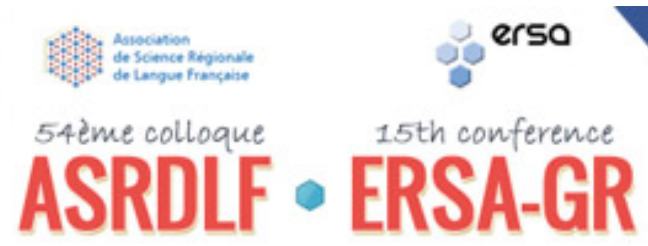

5-7 juillet 2017, Athènes, Grèce

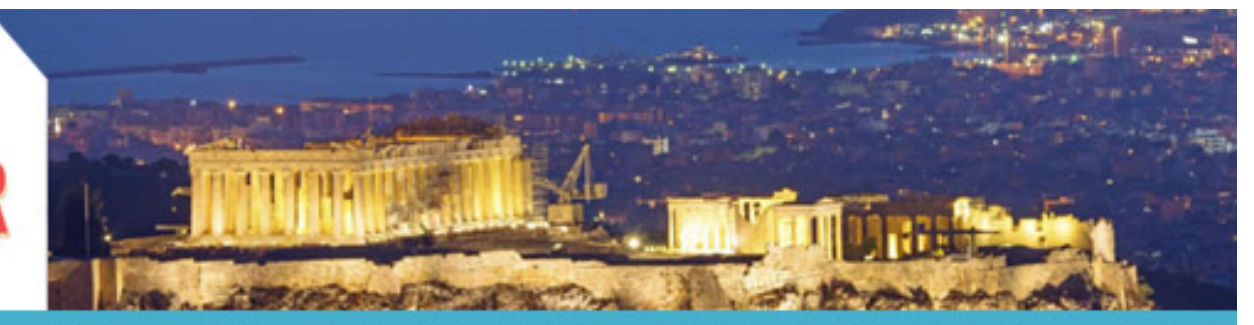

Les défis de développement pour les villes et les régions dans une Europe en mutation

Retail decentralization and land use regulation policies in suburban and rural communities: the case of the île-de-France region

\author{
Mr André TORRE \\ INRA Professeur \\ UMR SAD-APT, Agroparistech, 16 rue Claude Bernard 75231 Cedex 05 Paris \\ France \\ torre@agroparistech.fr \\ Mme Océane PEIFFER-SMADJA \\ INRA PHD Student \\ UMR SAD-APT, Agroparistech, 16 rue Claude Bernard 75231 Cedex 05 Paris \\ France \\ psoceane@gmail.com
}

Référence à la session / reference to the session

S 14

\title{
Résumé / Summary
}

The capacity for a suburban or a rural community to maintain retail activities in its town centre have often been considered as an indicator of its viability. But, since the 1970s, the expansion of new forms of retail, such as hypermarkets, shopping malls or retail parks has created a highly competitive environment for the small town centre retail units. Consequently, several central and local governments have developed rules in order to prevent an excessive development of large decentralized stores. In this paper, our goal is to assess the efficiency of land use regulation aiming at protecting existing retail units and its broader impacts on the size and localization of the retail stores in the Île-de-France region, the most populated area in France. The data we use over the 1975-2013 period include the evolution of small retail units, large retail stores and total retail floor space built at a local level. Using spatial statistics and econometric models we study the effects of land use regulation on retail patterns and local restrictiveness towards new large stores in the municipalities of the region during the last 40 years. We conclude that land use policies have impacted retail patterns in the region and that suburban and rural authorities, where town centre activities are crucial to their quality of life, are more restrictive towards large retail stores than urban ones.

\section{Bibliographie / Bibliography}


Basker, E. (2005). Job creation or destruction? Labor market effects of WalMart expansion. Review of Economics and Statistics, 87, 174-183.

Baum J., Paruchuri S., Potere D. (2009). The Wal-Mart Effect: Wave of Destruction or Creative Destruction? Economic Geography. 85(2), 209-236.

Bertrand, M., Kramarz, F. (2002) Does entry regulation hinder job creation? Evidence from the French retail industry. Quarterly Journal of Economics 117, 1369-1413.

Cheshire P. C., Hilber C. A., Kaplanis I. (2015) Land use regulation and productivity-land matters: evidence from a UK supermarket chain, Journal of Economic Geography 15 43-73.

Cliquet G. Garets V., Basset G., Perrigot R. (2008) 50 ans de grandes surfaces en France : entre croissance débridée et contraintes légales. Communication. 7th international congress, marketing trends, Venice, Italy, January 2008, 17-19.

Constans-Martigny C., Ruault J-F. (2012). Urbanisme commercial, Une implication croissante des communautés mais un cadre juridique à repenser. Rapport AdCF.

Delsaut P. (2001). L'immobilier d'entreprise et la procédure d'agrément en ile de France (1955-2000). Edition Broché. Janvier.

Glaeser E., Shleifer A. (2001). A case for quantity regulation. National Bureau of Economic Research Working Paper $n^{\circ}$ 8184. Available online at: http://scholar.harvard.edu/glaeser/files/w8184.pdf

Griffith, R., Harmgart, H. (2012). Supermarkets competition in England and planning regulation. The International Review of Retail, Distribution and Consumer Research Volume 22, Issue 1.

Guy C. (2010) Development pressure and retail planning: a study of 20-year change in Cardiff, UK, The International Review of Retail, Distribution and Consumer Research, 20:1, 119-133.

Haltiwanger, J., Jarmin, R., Krizan, C. J. (2010). Mom-and-pop meet big-box: Complements or substitutes? Journal of Urban Economics, 67, 116-134.

Haskel J., Sadun R. (2011). Regulation and UK Retailing Productivity: Evidence from Microdata. Economica, 79, 425-448.

INSEE (French National Institute for Statistics). (1998). Fidélité aux enseignes, fidélité aux marques : les choix des consommateurs. Collection Insee première. Septembre.

Joye J-F. (2007). Intégrer l'urbanisme commercial dans l'urbanisme général, Actualité Juridique Droit Administratif $n^{\circ} 20,1063-1071$.

Maican F., Orth M. (2012). A Dynamic Analysis of Entry Regulations and Productivity in Retail Trade. IFN Working Paper No. 939.

Monino J.-L., Turolla S. (2008). Urbanisme commercial et grande distribution. Etude empirique et bilan de la loi Raffarin. Revue française d'économie. 23, 2, 139-178.

Ronse, W., Boussauw, K., Lauwers, D. (2015). Shopping Center sitting and modal choice in Belgium: A destination-Based analysis. European Planning Studies, 2015 Vol. 23, No. 11, 2275-229

Sadun R. 2014. Does planning regulation protect independent retailers? Working paper. Review of Economics and Statistics (accepted).

Schearmur R., Alvergne C. (2003). Regional planning policy and the location of employment in the Île-de-France. Does Policy Matter? Urban Affairs Review, Vol. 39, No. 1, September, 3-31.

Schivardi F., Viviano E. (2011). Entry Barriers in Retail Trade. Economic Journal, 121(155), 145-170.

Thomas, C. J., Bromley, R. (2002). The changing competitive relationship between small town centres and out of town retailing: town revival in South Wales. Urban Studies, 39, 791-817.

Wrigley N, 1998. Understanding store development programmes in post-property-crisis UK food retailing. Environment and Planning A, 30 15-35. 